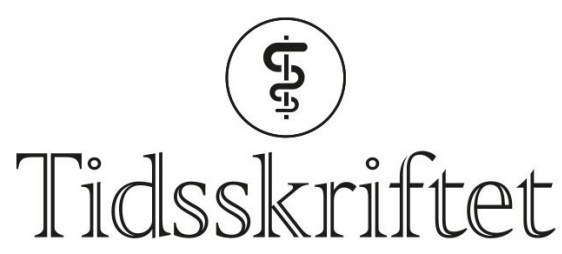

DEN NORSKE LEGEFORENING

\title{
Hva er det med disse skolebarna?
}

RETTELSE

BJØRN HANEBERG

SVENN-ERIK MAMELUND

SIRI MJAALAND

Tidsskr Nor Legeforen 2017; 137: 1484-5

I denne kommentaren i nr. 19/2017 hadde forfatterne Svenn-Erik Mamelund og Siri Mjaaland falt ut fra papirversjonen og nettpdf-en som er knyttet til nummeret. I tillegg skal referanse 1 s. 1485 være:

1. Didriksen J. Menneskelivets lykkeligste tid. Tidsskr Nor Legeforen 2017; 137:1089-90.

Vi beklager feilene, de er riktige på nett.

Publisert: 28. november 2017. Tidsskr Nor Legeforen. DOI: 10.4045/tidsskr.17.0977

(C) Tidsskrift for Den norske legeforening 2020. Lastet ned fra tidsskriftet.no 